\title{
A Fall Crow Roost and Possible Migration Near Saskatoon
}

\section{by J. Bernard Gollop, Canadian Wildlife Service}

On September 2, 1961, 15,700 crows were seen entering a stubble field southwest of the mouth of Beaver Creek, eight miles south of Saskatoon (NE 1-35-6 W3rd). They later moved into a willow and aspen grove immediately south of the field. Periodic checking thereafter resulted in a maximum estimate in excess of 52,000 on September 18 45,000 entering the roost in a 29minute period (6:56-7:25 p.m. CST). This "count" (by 10's, 100's and occasionally 1000's) was made from the east bank of the South Saskatchewan River just north of Beaver Creek. Birds were also noted entering the roost from the south but these could not be counted.

The next count was on September 24 from a point about a half mile south of the roost. An attempt was made to count only crows that could not be seen from the north. The estimate was 19,100 . About 70,000 crows were probably using the roost on September 18.

The most consistent and heavily used flight lines into the roost appeared to be from the east and southeast. A steady stream of birds usually arrived at the river one to four miles north and then flew over the west bank south into the roost (the river turns west at Beaver Creek). On October 4 the flight line from the southeast was traced back 14 miles from the roost; it passed within half a mile of the Strehlow elevator. Crows were occasionally seen arriving from the northwest and from due south. Flight lines varied somewhat from night to night. The only obvious factor causing this was shooting along the route.

All but the latest birds usually landed and spent some time on sand banks, in trees or in grain fields within a mile or two of the roost before entering it. Often part of the southeast population would pass east of the roost and congregate in trees a mile northeast of it.

On September 26, R. C. Caldwell of Ducks Unlimited and the author stationed themselves north and south of the roost for a complete count. On this occasion, most of the crows used a willow area a mile north of the regular roost and too far west for birds arriving from the north to be counted. There were often hunters at the regular roost.

No crows were seen in the vicinity of the roost on October 6 from $6: 15$ to 6.35 p.m., when it was almost dark.

This same roost may have been used in 1960. On September 9, 1960, 12,300 crows were counted flying east to the river from a point about four miles northeast of the 1961 roost. No attempt was made to locate the roost then.

In the course of other work on September 9, crows in good numbers were noted flying east from the vicinity of the roost at $11: 45$ a.m. CST., $1: 15$ and $3: 30$ p.m. At $4: 30$ an attempt was made to trace the route being taken. This ran six miles east from the mouth of Beaver Creek, then south-southeast for three miles along the railroad to a point one mile south of Haultain, and then southeast for about 14 miles where it was lost at 5:55 p.m. During this period of one hour and 25 minutes, 1,320 crows were observed along the route. (Between 7:25 and 8:00 p.m., 29,000 crows entered the roost from the north). If this was a migration from the area and if it went all day long it must have involved a lot of birds. Normally crows disperse from the roost at dawn.

\section{WHITE-BREASTED NUTHATCH CACHING FOOD}

by Ron Austin, Regina

On the afternoon of November 25, Margaret Belcher, Connie Pratt and myself noticed a White-Breasted Nuthatch on a piece of suet in the legislative grounds. This bird, after picking loose a piece of suet, would fly to another tree and hide this morsel of food in the rough bark of the tree. This done it would go back to the suet and begin the whole process again. I had observed this practice once before outside our apartment window and I suppose it is fairly common nuthatch behaviour. 